\title{
Efficiency Of Islamic Banks During Subprime Crisis: Evidence Of GCC Countries
}

Zied Ftiti, IPAG Business School-Paris, France and University of Tunis-ISG, Tunisia Olfa Nafti, University of Manouba, Tunisia

Safa Sreiri, University of Carthage, Tunisia

\begin{abstract}
This paper investigates the efficiency of the Islamic bank in GCC countries around the subprime crisis of 2008. The score of efficiency is evaluated by using the Data envelopment approach (DEA). Two different approaches are evaluated; the constant return scale (CRS) and Variable return scale (VRS). Then, a regression panel analysis is employed to examine the relationship between efficiency scores derived from the DEA to a set of explanatory variables combined between macroeconomic variables and microeconomic variables. The main finding of this paper is to show that the Islamic bank remains efficient under subprime crisis.
\end{abstract}

Keywords: Islamic Banks; Efficiency; Subprime Crisis; DEA Approach; Panel Regression Analysis; Bootstrap Technique

\section{I- INTRODUCTION}

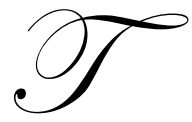

he globalizations of financial markets and the competition growth in the banking sector have posed new challenges in terms of research on the topic of efficiency of financial institutions, specifically banks. Since its emergence, about three decades ago; Islamic banking has become one of the industry's fastest growing in the Middle East particularly in the GCC region. Globally, Islamic banking has increased significantly reflecting a massive demand for Islamic financial products and services (Danesh, 2007). In addition, Islamic banks have been able to conquer many non-Muslim countries, operating side by side and in full competition with conventional banks (Hasan, 2004). Since the opening of the first Islamic bank in Egypt in 1963, Islamic banking has been growing rapidly worldwide. This new trend is even more intensified with soaring oil prices in 1975, which has introduced a huge amount of capital to Muslim countries (Sufian and Muhd-Zulkhibri, 2007).

The Islamic assets grew 11\% annually over the past decade in the Persian Gulf (Hassoune, 2010). While some see it as a vast deception, and a better successful marketing campaign, others acknowledge the financial future of the Muslim world (Hassoune, 2010). Little research has investigated the efficiency of Islamic banks (El-Gamal and Inanoglu, 2005). Some of them (Kiyota, 2009; Chapra, 2008) have discussed the efficiency of banks during times of crises.

Indeed, the two years 2008 and 2009 were the scene of a major financial crisis that hit the conventional financial system in its entirety. However, according to the above studies, Islamic banks were not much threatened and no studies have addressed their efficiency in the context of the subprime crisis.

Some researchers believe that Islamic banks are at least as efficient as conventional banks (Sarker, 1999). Others believe that Islamic banks are far more efficient than their conventional counterparts (El-Gamal and Inanoglu, 2005). Thus, the objective of this work is to study the efficiency of Islamic banks to disclose the impact of the subprime crisis on Islamic banks. 
Few researchers have mobilized the nonparametric Data Envelopment Analysis (DEA) to measure efficiency of Islamic banks (Yudistira, 2004; Sufian, 2007; Danesh, 2007; Sufian, 2009; Kamaruddin et al., 2008; Hamim et al., 2008). Based on the approach DEA, we will try, at a first level, to measure the efficiency scores of Islamic banks operating in the GCC region. At a second level, with linear regression, we will try to explain the efficiency of these banks here based on various macroeconomic factors (environment and characteristics of the country) and micro (Specific bank).

Our decision to retain the GCC countries in the region comes from the fact that most of the Islamic banking business is concentrated in the Middle East, particularly in the GCC. This region represents $85 \%$ of total assets of Islamic banks. Indeed, with over 300 Islamic banks worldwide in 75 countries, GCC controls two thirds of the market. In addition, the economies of the GCC region have several characteristics in common, including their dependence on oil exports accounting for $70 \%$ of the profits of the GCC. Other similarities include a common language (Arabic), a family-oriented culture and a stable political environment. The result of our study shows that the GDP by purchasing power and population density are positively and significantly correlated with the efficiency of Islamic banks. However, the quality of management is negatively correlated with efficiency. The coefficients on asset quality and profitability are not significant and have no direct relation to the efficiency of Islamic banks.

The remainder of this paper is organized as follows. Section 2 presents the related literature. Section 3 is describes the methodology and data. Section 4 reports and discusses the obtained results. Section 5 concludes the paper.

\section{II- RELATED LITERATURE}

Many researchers have attempted to check the efficiency of Islamic banks according different methodology. In this section we discuss the most important contribution by making out the different methodologies that was be used. This literature can be divided on three strands. Some of them explain the performance of Islamic banks by management factor, others they explain them according macroeconomic factor and some studied make out the performance of Islamic banks according a comparison with the conventional bank.

Hassan (2005) analyses the efficiency of Islamic Banking industry by employing a panel of banks during the period 1993-2001. Two approaches are used in this analysis: a parametric approach which consists on Stochastic Frontier Approach (SFA) and a non-parametric one which consists on Data Envelopment Analysis (DEA). This later is employed to determine different measures of efficiency ${ }^{1}$. According the SFA approach, he found that the Islamic Banks are more efficient in terms of profits than the conventional banks. In addition, he identify that the main source of inefficiency in Islamic industry consist on the allocative inefficiency rather than the technical one. He the management quality measure has a negative and significant impact on the efficiency of Islamic Banks. These result are similar to those identify by Deyoung (1997).

Sufian and Muhd-Zulkhibri (2007) analyse the performance of Malaysian Islamic bank during the period of 2001-2005. The main purpose of this paper consists to evaluate the performance of domestic Islamic banks and foreign Islamic bank in case of Malaysia. In objective to decompose the overall technical efficiency on pure technical component and a scale efficiency component, authors use two approaches of DEA analysis. The first one is carried out under a constant return to scale assumption and the second one is done with variable return to scale assumption. According this methodology, the authors show that the scale inefficiency dominates pure technical inefficiency in the Malaysian Islamic banking sector. They found that foreign banks have exhibited higher technical efficiency compared to its domestic peers. In order to explain the determinants of technical efficiency scores derived from the DEA models, authors use multivariate Tobit Regression Analysis. The main objective behind is to link the variation in calculated efficiencies to a set of variables: bank size, ownership, capital, non-performing loans and management quality. The result suggests that favorable macroeconomic environment seems to stimulate higher efficiency. Consistent with earlier findings, higher growth rate of GDP seem to have a strong positive impact on the performance measures, suggesting that demand for financial services tends to grow as economies expand and

\footnotetext{
${ }^{1}$ The different measures of efficiency are the cost efficiency, the allocative efficiency, technical efficiency, pure technical efficiency and scale efficiency. 
societies become wealthier. On the other hand, the findings suggest that technical efficiency is negatively related to market power, risk, management quality and capitalization. The result show that technically more efficient banks are larger, have greater loans intensity, and on average have less non-performing loans.

Ghayad (2008) analyse the performance of Islamic banks by analysing their degree of operations. In his work, he interested to corporate governance in Islamic banks and his influence on the global performance in the case of Bahrain. In his analysis, Ghayad focus on the simultaneous existence of monitoring committee ${ }^{2}$ with Islamic bank manger's board. According to Ghayad (2008), the contribution of Shari'a board in banks governorship impose an important constraints one Islamic banks operation. Consequently, the investment account holder (IAH) didn't contribute to the management of their funds. In other words, the corporate governance of Islamic banks does not give to the IAH any power to appoint the management or the external auditor. This situation raises interest conflict between IAH and the Islamic bankers: it is same conflict which exists between "principal-agent" relationships in conventional firms. In this analysis, Ghayad (2008) show that in addition to quantitative international variables such as the financial ratios, the performance of an Islamic bank is affected also by the internal qualitative variables like the managerial variables. The main finding of this paper consists on the fact that the members of Shari'a board represent a serious handicap for the directors of the Islamic banks. Directors and members of Shari'a board did not speak the same language. The members of the Shari'a board were not very specialized in the fields other than Sheri's and contrary the directors in Shari'a. Kamaruddin et al. (2008) investigates for the first time, both cost and profit efficiency of full-fledged Islamic banks and Islamic window operations of domestic and foreign banks in case of Malaysia. He adopts the DEA approach to estimate different measures of efficiency. The main finding of this paper consist on proving that Islamic banking operators are relatively more efficient at controlling costs than at generating profits. The main contributor for cost efficiency of domestic and foreign banks comes from resource management and economies of scale respectively. These findings have implications on the reform process carried out in the aftermath of Asian financial crisis, particularly the Financial Sector Master Plan (FSMP).

The above studies show that the principal determinants of Islamic banks performance are the management variables. A second kind of literature shows that the macroeconomic indicators can explain the efficiency of Islamic banks. Haron (2004) investigates the determinants of profitability of Islamic banks. According a panel data regression, he found that internal factors such as liquidity, total expenditures, funds invested in Islamic securities, and the percentage of the profit-sharing ratio between the bank and the borrower of funds are highly correlated with the level of total income received by the Islamic banks. Similar effects are found for external factors such as interest rates, market share and size of the bank. Haron (2004) identified other determinants of Islamic bank profitability such as funds deposited into current accounts, total capital and reserves, the percentage of profit-sharing between bank and depositors, and money supply. The similarity of results between asset-liability management and profitability for both conventional and Islamic banks is a strong indicator that many of the tools and techniques developed in conventional banking literature are potentially suitable for an Islamic banking environment. Indeed, interest rates, inflation and size have significant positive impact on the profits of conventional banks. This positive relationship is also identified in the case of Islamic bank (Haron, 2004). In the case of market share and money supply, these variables were found to have an adverse effect on profits.

Hassan and Bashir (2003) studied the effects of controlled and uncontrolled variables on Islamic banks profitability during 1994-2001. They show that some economics variables such; capital, gross domestic product and conventional interest rates were positively related to profitability. However, loan ratios, reserves taxes, and size have a negative impact on profitability of Islamic bank.

Loayza and Shankar (2000) used cointegration approach in measuring the relationship between savings in India and factors such as real interest rate, per capita income, the dependency ratio, financial development, the government saving rate, and the share of agriculture in gross domestic product (GDP). Their results revealed that real interest rate, per capita income and the share of agriculture in GDP had a positive relationship with savings, whereas inverse relationship were found for financial development, inflation and the dependency ratio. Loayza and Shankar (2000) investigated the effects of policy and non-policy variables on savings and reported that: (1) private

\footnotetext{
${ }^{2}$ The committee monitoring has a supervising mission. In other word, they take care of the conformity of Islamic banks activities with Shari'a religion.
}

(C) 2013 The Clute Institute http://www.cluteinstitute.com/ 
saving rates are highly serially correlated, (2) positive saving rates with the level and growth rate of real per capita income and the influence of income is larger in developing than in developed countries, (3) life cycle hypothesis is supported by the negative relationship between dependency ratio and saving rate, (4) inflation was found to have a positive impact on saving thus supporting the precautionary motive for saving, (5) fiscal policy is a moderately effective tool to raise national saving, and (6) financial liberalization is detrimental to private saving rates because greater credit availability reduces saving rate and similarly larger financial dept and higher real interest rate do not increase saving.

A third kind of literature evaluates the performance of Islamic Bank by making a comparison with conventional bank. Hanim and al. (2008), investigate the efficiency of the fully fledged Islamic banks as well as Islamic windows in Malaysia. They measure the technical and costs efficiency by the DEA approach. They show that, despite the fully fledged Islamic banks were more efficient than the Islamic windows; they were still less efficient than the conventional banks. They prove that Islamic windows of the foreign banks were found to be more efficient than Islamic windows of the domestic banks.

Danesh (2007) investigate the efficiency of Islamic bank in a comparison to their Conventional counterparts in the case of the Gulf Cooperation Council (GCC), during the period 2000-2006. Firstly he uses the DEA analysis to estimate the relative efficiency. ${ }^{3}$ After that, he examines the determinants of Islamic Banking efficiency using a second-step regression model approach. The main result of this paper proves those Islamic banks are more efficient in 2006 than the conventional counterparts. This result traduce the feasibility of Islamic Banks structure for real estate construction and project finance investments as well as the increased confidence of consumers in Islamic banking from both aspects Sharia'a transparency and profitability generation capacity.

Wilson (2009) investigates the case of Islamic finance in GCC region. The main purpose of this paper is to identify the major factors explaining the expansion of this kind of finance. Wilson (2009) shows that Islamic financial institutions in this region are significant sources of capital and are contributing to the development of Islamic finance worldwide, especially in Asia.

The paper of Lozano-Vivas and Pasiouras (2010) studied the relevance of non-traditional activities in the estimation of bank efficiency levels using a sample of 752 publicly quoted commercial banks from 87 countries around the world. The main of this paper consists on allowing comparison of the impact of such activities under different levels of economic development, geographical regions and other country characteristics. The authors estimate three functions. They started by estimate both cost and profit efficiency of banks using a traditional function that considers loans and other earnings assets as the only outputs. After that, they estimate two additional functions to account for non-traditional activities, one with off-balance sheet (OBS) items and the other with noninterest income as an additional output. They find ${ }^{4}$ that, on average, cost efficiency increases irrespective of whether they use OBS or non-interest income, although the results for profit efficiency are mixed. In addition, they show that while the inclusion of non-traditional outputs does not alter the directional impact of environmental variables on bank inefficiency, regulations that restrict bank activities and enhance monitoring and supervision provisions improve both cost and profit efficiency.

\section{III- METHODOLOGY AND DATA}

The main objective of this paper consists on analyze the implication of subprime crisis on the efficiency of Islamic bank in the GCC region. Behind the lack of consensus on the Islamic bank efficiency, our analysis is important for many reasons.

Firstly, there is a first study which analyzes the efficiency of Islamic Bank during the subprime crisis. Indeed, we know the implication of loans crisis on conventional banks. So it is important to make out the implications of this crisis on the efficiency of Islamic bank. Secondly, in our study we combine two kinds of determinants Islamic banks efficiency: the microeconomic determinants and macroeconomics ones. Thirdly, there are a less studies which analyze efficiency banking in the GCC region.

\footnotetext{
${ }^{3}$ The sample contains 12 Islamic banks and 38 conventional one.

${ }^{4}$ By controlling for cross-country differences in regulatory and environmental conditions. 


\subsection{Efficiency Measure}

\subsubsection{Data envelopment approach (DEA)}

At the beginning, it is useful to define adequately the efficiency concept and its robust method estimation. In general, it is the quality of return allowing the realisation of objectives with minimum of resources. This concept must be none confused with relevance and profitability. Efficiency is a financial concept which evaluates outcome via results reported to capital invested. At conclusion, Efficiency is a relative concept since its measurement requires a standard of performance against which the success/failure of the firm is assessed. It is an indicator of how resourceful a firm is in producing outputs.

Efficiency measurement is one aspect of investigating a firm's performance. Efficiency is divided into two components. There are the output efficiency and input efficiency. A firm is regarded as technically efficient if it is able to obtain maximum outputs from given inputs or minimise inputs used in producing given outputs. The output efficiency is related either to the production of an optimal levels of outputs (scale efficiency), or to an optimal combination of different outputs (technical efficiency). However, the inputs efficiency is related to the capacity of the firm on minimizing inputs used in producing given outputs (X-efficiency).

Roughly speaking, empirical studies employed three kinds of methods to measure efficiency. Most of them (Elhiraika, 1998; Iqbal et al., 2000...) used some financial ratios such investment ratio (ROI) and profitability ratio (ROA). The main objective of this methodology consist to compare, according these ratios, the bank's performance under the studied period to last period or to other neighbouring banks. Two mains criticizes are addressed to this method. Firstly, it doesn't take into account the managerial actions. Secondly, it combines the efficiency sources and the inefficiency one which deny us to know the nature of the operation. The contemporary studies employed parametric or nonparametric frontier techniques to measure the efficiency of firms relative to an estimated 'bestpractice' frontier that represents the optimal utilization of resources. Both approaches differ mainly in how they handle the random error and the assumptions made on the shape of the efficient frontier. The parametric approach has the advantage of allowing noise in the inefficiency measurement. However, it involves econometric estimation of a pre-specified stochastic profit, production or cost function. In the other side, nonparametric data envelopment analysis (DEA) ${ }^{5}$ approach does not require the specification of a particular functional form of the frontier. Instead, the frontier is constructed through a piecewise linear combination of the actual input-output correspondence set that envelops the data of all the firms in the sample. Hence, efficiency measurement is not contaminated by a possible misspecification of the functional form.

The DEA approach measures the efficiency of each decision Making Units (DMUs) as a function of multipliers input-outputs combination. In the literature, two major assumptions are investigated under the DEA approach; the constant returns to scale (CRS) assumption. Under this assumption there is no significant relationship between the scale of operations and efficiency which delivers the overall technical efficiency (OTE). However, firms or DMUs in practice might face either to scale economies or to scale diseconomies. Thus, if one makes the CRS assumption when not all DMUs are operating at the optimal scale, the computed measures of technical efficiency will be contaminated with scale efficiencies. The second assumption comes with Banker et al. (1984) by relaxing the CRS hypothesis. They assess the efficiency of DMUs characterised by variable returns to scale (VRS). The VRS assumption provides the measurement of pure technical efficiency (PTE), which is the measurement of technical efficiency devoid of the scale efficiency effects. If there appears to be a difference between the TE and PTE scores of a particular DMU, then it indicates the existence of scale inefficiency. Behind the diversities between these assumptions, the most of studies presents their results under the CRS hypothesis. In this work, we differ from previous studies in checking either the two assumption CRS and VRS.

\subsubsection{Measure of the DEA}

In this paper, our objective consists to measure the efficiency scores of Islamic banks in GCC countries according the DEA approach. The approach is based on the following program:

\footnotetext{
${ }^{5}$ The DEA approach was first introduced by Charnes, Cooperand Rhodes (1978).
} 


$$
\begin{aligned}
& \operatorname{Min} \lambda_{0} \theta_{0} \\
& \text { Subject to } \quad \sum_{j=1}^{n} \lambda_{0 j} y_{r j} \geq y_{r 0} \quad(r=1, \ldots \ldots \ldots \ldots, \mathrm{s}) \\
& \theta_{0} x_{i 0} \geq \sum_{j=1}^{n} \lambda_{0 j} x_{i j} \quad(i=1, \ldots \ldots \ldots \ldots, \mathrm{n}) \\
& \sum_{j=1}^{n} \lambda_{0 j}=1 \\
& \lambda_{0 j} \geq 0 \\
& (j=1,
\end{aligned}
$$

with $\theta_{0}$ : OTE; $\mathrm{y}_{\mathrm{r} 0}$ : Output $\mathrm{r}$ of $\mathrm{DMU}_{0} ; \mathrm{x}_{\mathrm{i} 0}$ : Input $\mathrm{i}$ of $\mathrm{DMU}_{0} ; \mathrm{y}_{\mathrm{rj}}$ : Output $\mathrm{r}$ concerning the unit of reference $\mathrm{j}$; $\mathrm{x}_{\mathrm{ij}}$ : Input $\mathrm{i}$ concerning the unit of reference $\mathrm{j} ; \lambda_{0 \mathrm{j}}$ : the weight of reference unit $\mathrm{j} ; \mathrm{s}:$ number of outputs; $\mathrm{n}:$ Number of DMUs.

The first constraint (eq.2) supposes that the reference output must at least the same level as the output of $\mathrm{DMU}_{0}$. The second one (eq.3) stipulates that used adjusted-efficiency input $\mathrm{DMU}_{0}$ must be greater than (or equal to) the used input of unit reference. Behind that the correction factor is the same for all kind of inputs, the observed inputs reducing is proportional. The third constraint-convexity constraint- (eq.4) was introduced to assume the VRS assumption: In other words, when we calculate the efficiency score under CRS assumption we dismiss this constraint.

According Fethi and Pasiourous (2010) most of studies that use two stage DEA do not employ appropriate the bootstrap technique and their results may be biased. To avoid the dependence bias, we choose the methodology of Xue and Harker (1999) to apply the bootstrap technique according five stages.

1- Firstly, we determine the probability distribution of the sampling $\hat{F}$ with each observed DMU of the sample $\left(\mathrm{x}_{1}, \mathrm{x}_{2}, \ldots, \mathrm{x}_{n}\right)$ has a probability of occurrence equal to $1 / \mathrm{n}$.

2- $\quad$ Learn $\mathrm{c}\left(\mathrm{c}\right.$ is a constant) random samples of size $\mathrm{n}$ to replace the original samples $\left(\mathrm{x}_{1}, \mathrm{x}_{2}, \ldots, \mathrm{x}_{n}\right)$,

$S_{k}=\left(x_{k 1}, x_{k 2}, \ldots, x_{k n}\right) \quad ; k=1,2, \ldots, c$

with $\mathrm{X}_{k i}=\left(\mathrm{U}_{k i}, \mathrm{~V}_{k i}\right), \mathrm{i}=1,2, \ldots, n ; \mathrm{S}_{k}$ is called the bootstrap sample. $\mathrm{U}$ and $\mathrm{V}$ represent respectively the inputs and outputs.

3- $\quad$ For each bootstrap sample $\mathrm{S}_{k}, k=1,2, \ldots, c$, we execute the DEA model and we recalculate the scores of efficiency for the $n$ DMUs:

$\Theta_{k i}=\varphi_{i}\left(\mathrm{U}_{k}\right) ; \quad i=1,2, \ldots, \mathrm{n}$

4- $\quad$ For each bootstrap sample $\mathrm{S}_{k}, k=1,2, \ldots, c$, we evaluate the bootstrap reproduction $\hat{\beta}_{k j}, k=1,2, \ldots, c, j=$ $0,1, \ldots, m$, according the following regression model:

$\Theta_{k i}=\mathrm{G}\left(\beta_{k}, \mathrm{~V}_{k i}\right)+\varepsilon_{k i} \quad i=1,2, \ldots, n ; \quad \beta_{k}=\left(\beta_{k 0}, \beta_{k l}, \ldots, \beta_{k j}, \ldots, \beta_{k m}\right)$

5- Estimate the standard error se $\left(\hat{\beta}_{j}\right)$ by the standard deviation of the sample of c reproductions bootstrap 


$$
\begin{aligned}
& \hat{s} e_{c}\left(\hat{\beta}_{j}\right)=\left\{\begin{array}{l}
\sum_{k=1}^{c}\left(\beta_{k j} \hat{-} \overline{\beta_{j}}\right)^{2} \\
(c-1)
\end{array}\right\}^{\frac{1}{2}} \quad \begin{array}{l}
j=1,2, \ldots, \\
m
\end{array} \\
& \text { Where, } \quad \overline{\beta_{j}}=\frac{\sum_{k=1}^{c} \hat{\beta_{k j}}}{c} ; \quad j=1,2, \ldots, m
\end{aligned}
$$

After these five stages of DEA bootstrapping technique we can test the following hypothesis:

$\mathrm{H}_{0}: \beta_{\mathrm{j}}=0$, Vs. $\mathrm{H}_{1}: \beta_{\mathrm{j}} \neq 0$

The main disadvantage of this DEA method consists on the difficulty to make statistics extrapolation. To deal with this limits, GrossKopf (1996), Coelli et al. (2005) and Casu and Molyneux (2003) propose a regression analysis. This solution is known as two steps procedures. It consists to explain the efficiency score variation according analysis regression. It consists to consider the efficiency score as data or index, and then they use the regression analysis to explain the score efficiency variations. This method is called as two-stage regression analysis.

\subsection{Panel Data Approach}

To further investigate the performance of Islamic Banks we obtain the efficiency scores (for two models: CRS and VRS assumption) from the DEA and perform a second-stage Regression analysis approach. According to Xue \& Harker (1999), "Regression analysis is among the most useful and most widely used statistical methods. It is a reliable and easy to use tool to determine whether or not certain factors influence the decision-making units' (DMUs) efficiency scores". Furthermore, it is argued that banks could be considered inefficient because they undertake different types of services or probably more costly services. Thus several studies have highlighted this issue and investigated the relationship between some factors like size, profitability, share market, etc, and the efficiency scores obtained from the DEA such as Miller \& Noulas (1996). For the analysis, we examine a cross sectional data of several banks in GCC countries over the period of 2005 to 2009. Thus, we need a technique that has two dimensions, cross-sectional and time series. To address this problem, we used the Panel data approach, because Panel Data refers to a group of cross-sectional units being surveyed over a period of time. So, each bank will be observed every year over the 5-years. This is called the 'balanced panel'.

\subsection{Choice of inputs and outputs and data sample}

\subsubsection{Specification of Bank inputs and outputs}

The choice of the variables in inefficiency studies affects significantly the results (Berger et al., 1993; Wheelock et al., 2000 ...). There is an on-going discussion in banking literature regarding the proper definition of inputs and outputs. Three approaches dominate the literature: the production approach, the intermediation approach and more recently, the revenue approach. Under the production approach, pioneered by Beston (1965), the bank is defined as a producer of services for account holders. This approach considers the number of account or its related transaction as the best measure of output, while the number of employees and capital resource are considered as input (Suffian 2009). However, the intermediation approach, pioneered Sealey and Lindley (1977), considers the bank or financial firms as intermediary between savers and borrowers and posits total loans and securities as output, while deposits along with labor and physical capital are defined as input. Recently, Drake et al. (2006) proposed the revue approach in DEA. Under this approach balance sheet, deposits and loan are defined as output.

In this work we opt for intermediation approach. This choice is justified by many reasons. The first one concern the main character of Islamic banks which is often claimed as a joint stock firms which shares are easily tradable (Dar and Presley 2000). The principle of Islamic financial system is the participation in enterprise, 
employing the funds based on profit and loss sharing. ${ }^{6}$ Secondly, the intermediation approach is preferable to the other approaches to modeling bank behavior, according to Elyasiani \& Mehdian (1990). This is because it does not exclude interest expenses, which accounts for a significant level of banks' total costs where the exclusion of interest expense may distort efficiency estimates.

In specifying inputs, our work reflects the standard intermediation approach in which capital and labor are used to intermediate deposits into loans and other earning assets. In particular, the capital input is represented by fixed assets, while the labor input is represented by personnel expenses. In most DEA studies, the number of employees is common to specify input. However, in this study we evaluate many countries; the general analysis will therefore benefit from the inclusion of personnel expenses in monetary values instead of number of employees.

On other hand, the inclusion of other revenue in the analysis is particularly important as Islamic banks have been very creative in avoiding interest rate products which creates the movement from traditional financial intermediation into off-balance sheet alike and fee income-generating businesses (Dar 2003). As a result, according (Yudistira, 2004), concentrating on completely earning assets would be insufficient to capture the overall output of Islamic banking industry. Furthermore, total loans of Islamic banks in the sample consist of mostly Islamic transactions.

The DEA method is very sensitive to the number variables. Their increasing reduces the ability to distinguish of decisions units (DMUs). Thus, selecting the appropriate variables to measuring banking efficiency is very important. This is because efficiency estimations would possibly differ if a different set of variables were applied. To preserve the discriminatory power of DEA, we must ensure that the number of input and output is reasonable quantities. According to the literature we opt for 3 inputs and 3 outputs.

Table 1 -Islamic banks Inputs and Outputs adopted for the efficiency measure

\begin{tabular}{cc}
\hline \hline Inputs & Outputs \\
\hline \hline Work (represented by staff charges) & Total loans \\
Equity (represented by the fixed assets) & Other revenues \\
Total deposits & Liquid Assets \\
\hline \hline
\end{tabular}

\subsubsection{Data Sample}

The main contribution of this paper consists on combining the microeconomic variables and macroeconomic variables to explain the efficiency of Islamic banks. We refer to literature for selecting the appropriate variables. According literature we retain three macroeconomic variables and six microeconomic one variables. The retained variables are presented in the following table:

Table 2: Descriptive Statistics of variable used in the regression

\begin{tabular}{llcc}
\hline \hline \multicolumn{1}{c}{ Variable } & \multicolumn{1}{c}{ Description } & \multicolumn{1}{c}{ Measure } & $\begin{array}{c}\text { Literature } \\
\text { Results }\end{array}$ \\
\hline \hline$A Q$ & Assets Quality & Provision on loans accorded / total of loans. & - \\
$M Q$ & Management Quality & General expenses / total assets & - \\
$L Q$ & Liquidity & Total loans accorded / total assets. & + \\
$\mathrm{ROA}$ & Return On Assets & Net Result / Total Assets & + \\
$R O E$ & Return On Equity & Net Result / Total equity & $+/-$ \\
$B S$ & Bank size & Natural logarithm of total assets. & + \\
$M S$ & Market share & Natural logarithm of total deposits. & $+/-$ \\
$G D P$ & Gross Domestic Product & Natural Logarithm of the country's Gross Domestic Product & $+/-$ \\
& (GDP). & - \\
$I N D$ & Population density & Country's population density. & $+/-$ \\
$\mathrm{RCP}$ & Concentration & Herfindahl-Hirschmann Index that corresponds to the squares & $+/-$ \\
\hline \hline
\end{tabular}

${ }^{6}$ This by no means implies the importance of intermediary activities that Islamic banks perform. 
The microeconomic variables (Assets quality, management quality, liquidity, bank profitability ${ }^{7}$ bank size and market share) are collected from individual annual report which there available in the web site of each bank. However the macroeconomic variable (Gross domestic product, population, concentration) are collected from International Monetary Fund data base (IFS). According Casu and Molyneux (2000), all variables are converted to USA dollars by using the stock change end period.

Our sample covers 30 Islamic banks in GCC region during the period 2005-2009. Our motivation to GCC region resides on the fact that most important Islamic bank activities are concentrated in this region (85\% of all world Islamic bank activities). The choice of the studied period is motivated by our objective to check the impact of loans crisis on the Islamic banks.

\section{IV- $\quad$ RESULTS AND DISCUSSIONS}

\subsection{Primary analysis}

Appendix A presents a summary of descriptive statistics of Banks inputs and outputs (respectively Table 4 and Table 5). According Table 4, we observe a constantly increase of the average deposits during the studied period. This stylized fact confirms the thesis popularity increase of Islamic banking especially in crisis period. The same fact is observed in another input: equity. These facts let us to guess that Islamic banks are very healthy and continue to evolve from one year to another.

According Table 5 (Appendix A), we observe a widely progress on the average of the Islamic banks financing between 2005 and 2009. It passed from 2 018,349 in 2005 to 12 563,930 in 2009. Behind these facts, we can said that the Islamic banks are actually expanding and acquiring, more and more, market shares.

In addition, the average of other revenues ${ }^{8}$ is steadily rising between 2005 and 2009. According Tables 4 and 5 (Appendix A), we observe that all revenues didn't decrease during the subprime loans crisis. In 2008 and 2009, all revenues are raised. So, we can conclude warily that the Islamic bank activities didn't affected by crisis.

The Table 6 (Appendix B), presenting the descriptive statistics of dependant variables per year for CRS and VRS hypothesis, shows that the average efficiency score for an Islamic bank is 0,8 . This shows that Islamic banks are, generally, efficient.

We know that the Bank assets have a good quality when their equity ratio is lower. ${ }^{9}$ Table 7 (Appendix B) shows that the equity ratio (ER) of Islamic banks in our sample has a mean equal to 0,896 even though the maximum is equal to 6,688. In addition, in our Islamic banks sample have good quality assets according the level of the assets quality ratio which has a mean equal to 0.047 . Other variable which traduces the Islamic bank position consists on the management quality. Table 7 tells us some information about the management quality ${ }^{10}$. It has a mean of 0.035 compared to a maximum of 0.62 . We note that there are Islamic banks with negative ROA and ROE with a minimum, respectively, of $-2,160$ and $-7,397$. This is explained by the fact that certain banks had negative results, but the average is positive. There are few banks, in our sample, which had recorded nets deficits.

Concerning the size variable, we notice that our sample is composed largely of medium-sized banks. Indeed, it's clear that the bank's size is between 0 and 183,117 USD and that the sample mean is 39,439 USD with a standard variation of 41,270 USD. The country with the highest number of Islamic banks belonging to our sample is Bahrain. Indeed, it represents 56, $67 \%$ of our sample.

\footnotetext{
${ }^{7}$ This variable is measured by ROA and ROE.

${ }^{8}$ These revenues are coming from Islamic banking activities.

${ }^{9}$ This ratio is measured by the provision of total loans accorded over total loans.

${ }^{10}$ The management quality is measured by the total general expenses over the total assets. When this measure is lower, the management quality is qualified by good.
}

(C) 2013 The Clute Institute http://www.cluteinstitute.com/ 


\subsection{Efficiency of Islamic Banks}

\subsubsection{Results of Efficiency Score (DEA Approach)}

Table 6 (Appendix B) displays the results of DEA measure of Efficiency score under CRS hypothesis. Efficiency scores are always between 0 and 1. The bank which has an efficiency score equal to 0 is totally inefficient, while, an efficiency score equal to 1 is evidence of a very efficient bank. According Table 6 (Appendix B), the average of efficiency scores of Islamic banks in our sample, measured under the assumption of CRS, vary between 0, 59 and 1. In our sample, the more efficient banks, which have an efficiency score equal to 1, are Al Amine and Citi Islamic, two banks operating in Bahrain. However, those that appears to be the less efficient, relative to banks in our sample, has an average of efficiency score equal to 0,59; there are Investor TII (Kuwait) and Emirate Islamic Bank (United Arab Emirates). We explain this heterogeneity between Islamic bank in GCC countries through their degree of technology, (Abhiman and Saibal, 2009). Kamaruddin et al. (2008) suggest that bank with an efficiency core equal to 1 traduce the power over market of this bank and imply it monopolistic position.

Figure 3 (Appendix B) presents the averages of efficiency scores, under the CRS assumption. According this figure, we show that the Bahrain is the country containing more than $50 \%$ of banks in our sample and it is the country having the highest mean efficiency of Islamic banks; equal to $87 \%$. Bahrain is nearly followed by Qatar with $82 \%$. Then, we find Kuwait and UAE, respectively with $74 \%$ and $69 \%$. Finally, the Saudi Arabia, with average efficiency scores of $62 \%$, it comes in second last position of GCC countries.

Contrary to the results obtained under CRS hypothesis, the VRS model shows that Qatar became the leader with an average efficiency scores equal to $91 \%$ closely followed by Bahrain with $89 \%$. Then, we found Saudi Arabia, the UAE and Kuwait with, respectively, $80 \%, 76 \%$ and $75 \%$. By measuring the efficiency under the VRS assumption, we notice that there are many banks very efficient banks, that is to say, with an average efficiency score equal to 1. Such is the case of Al Amine, Al Salam, Al Baraka Banking Group, Citi Islamic and Rajhi Bank (Figure 4, Appendix B).

If we make a comparison between the efficiencies scores measure under the two assumptions CRS and VRS, we conclude that the number of highest efficiency banks is higher under the VRS assumption than the CRS one. Excluding Al Amine and Citi Islamic, the other banks cited above were not consider among the most efficient, under the constant return to scale hypothesis. One might ask why the banks are more efficient under VRS assumption than under the CRS assumption. We explain these results by the fact that the CRS assumption is only sustainable when all the banks operate at optimal scale. According Coelli et al. (2005), imperfect competition, government regulations and financial constraints are sufficient reasons that make the bank not to operate at an optimal scale. Concerning the less efficient banks in our sample, there are the same under VRS and CRS assumptions.

\subsubsection{Efficiency Crisis}

Since the ninety decade, multiple economic crises occurred in the word rising financial instability. Banking crisis are the most spectacular form of this instability. Honohan (1997) two-thirds of IMF member countries have been hit by severe banking crisis that have resulted in cumulative losses exceeding 250 billion dollars. In addition, more than 130 countries, representing three quarters of IMF member countries, have experienced significant bank failures (Lindgren, Garcia and Saal, 1996). Bank failures can be explained by the speculative behavior allowed by financial liberalization and globalization. Several empirical studies showed that banking crises were, generally, preceded by financial liberalization policies, (Miotti and al., 1998).

The various works have addressed this issue highlight a common cause to explain the bank failures: an excessive risk taking by banks related to moral hazard. Under financial liberalization environment, bank failures are a result of poor policies followed by banks in terms of risk management, (Gonzalez-Hermosillo, 1999). The legal and regulatory environment of financial liberalization encouraged the bank's shareholders and managers to take more risks. This is explained by a lower profits (and potential losses) related to higher degree of competition reduces 
the bank's economic value. The bankruptcy cost being undervaluated by bank's shareholders and managers which favoring the choice of riskier strategies, (Caprio and Summers, 1993; Hellmann, Murdock and Stiglitz, 2000). Therefore, speculative behavior and excessive risk taking from banks is related to the functioning of free and competitive markets.

Plihon (1996) distinguish four principals' characteristics of speculative transaction. Firstly, excessive risktaking which mean taking a position on interest rate, exchange rate, assets prices. Secondly, these operations are motivated by the hope of capital gains related to their anticipations of assets process evolutions. Thirdly, these transactions are "pure" or "dry"; they are self-sufficient and have no direct counterpart in the real economy. Fourthly, the capital employed is borrowed by speculators seeking to benefit from leverage effect. So, we can conclude that, Banks and financial system, poorly controlled by inadequate prudential monitoring devices, are weakened by excessive risk taking leading to the emergence of speculative bubbles and an acceleration of money creation. However, Islamic banks have special characteristics which make them impervious to crises. Islamic banks are constrained to follow some rules avoiding speculative behavior. Their requirement to real assets protects them to be affected by crisis. In this part, we try to analyze the efficiency of our Islamic banks sample under the loans crisis. We analyze the efficiency score pattern under VRS and CRS respectively according the following Figure 1 and 2:

Figure 1- The pattern of efficiency score under VRS assumption (2005-2009)

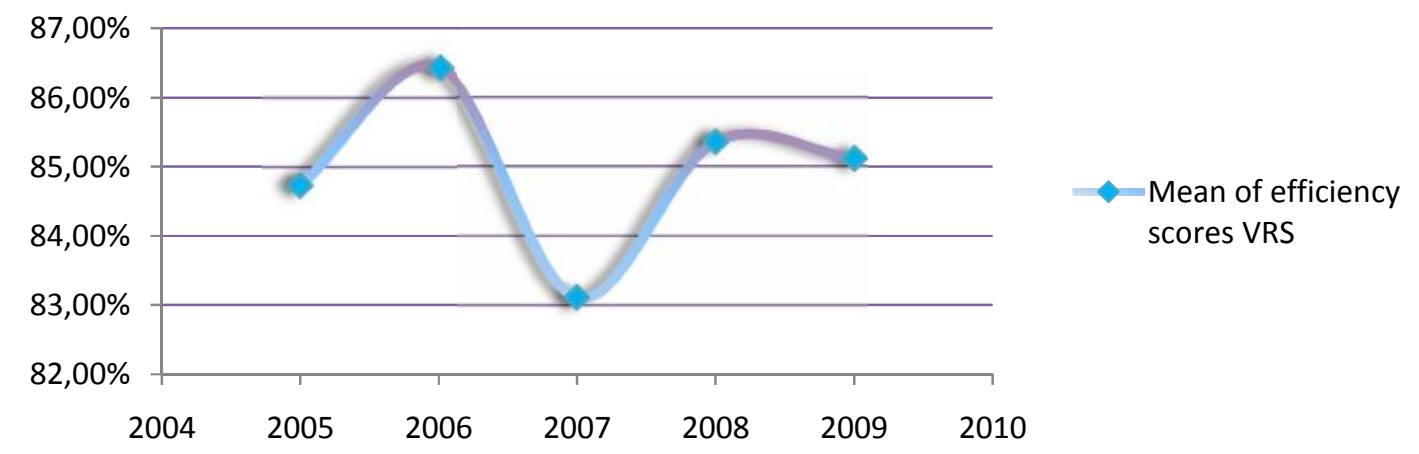

Figure 2- The pattern of efficiency score under CRS assumption (2005-2009)

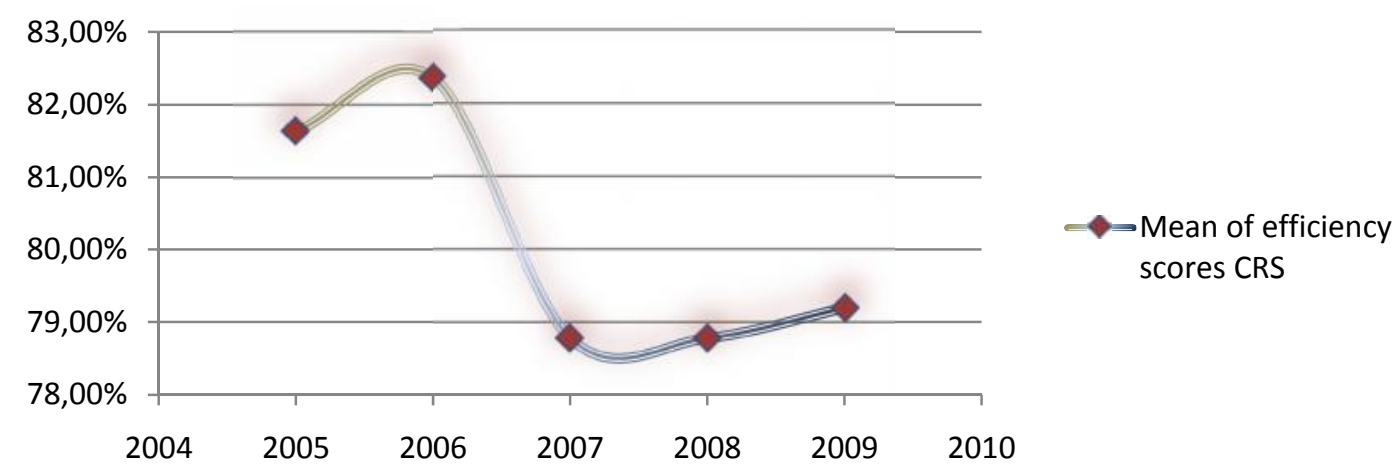

Figure 1 shows the variation of efficiency scores under VRS assumption of our Islamic banks sample during the period 2005-2009. According Figure 1, efficiency scores have not changed a lot during the studied period. It varied between 0,83 and 0,865 . The efficiency score is slightly decreased in 2007 , then it increased in 2008 and become stable in 2009 with an average equal to 0,85 .

Figure 2 shows the variation of efficiency score under CRS assumption of our Islamic banks sample during the period 2005-2009. According this figure, the efficiency score varies between 0,785 and 0,825. The maximum average efficiency measured under CRS assumption $(0,826)$ does not reach the minimum of the average efficiency measured under the VRS assumption $(0,83)$. This shows that banks are generally more efficient when efficiency 
scores are measured under variable return than the constant scale. However, under the subprime loans crisis, Figure 2 shows that the Islamic banks have not been affected by the crisis. Indeed, after a drop in 2007, the efficiency score has resumed its upward trend reaching in 2009 an average equal to 0.792 . According Figure 2, the efficiency score (under CRS) is higher in 2008 and 2009 than 2007. In other words, the Islamic banks continue their efficiency growth despite the subprime crisis.

Many points can explain these results. Firstly, Islamic banks are based on completely different rules from those adopted by conventional banks; the outputs offered by Islamic banks are always backed by real assets and are not based on fictitious assets as do conventional banks. Secondly, sectors where Islamic banks operating are limited compared to conventional banks, which does not allow them to take excessive risks. Thirdly, most of the causes contributing to financial crisis are not applicable to Islamic banks, because these do not meet the same criteria as conventional banks, then it seems legitimate that Islamic banks and the entire Islamic financial system are not affected by this kind of financial crisis.

It is not surprised in this work to found that the subprime loans crisis didn't affect Islamic banks in GCC region, but the most surprised one concerns that this crisis is beneficial to these kinds of banks. We explain this by the confidence crisis on conventional banks, occurred during the crisis, which lead investors and savers to move from traditional financial system to Islamic banks system.

\subsubsection{The determinants of Islamic bank efficiency : Regression analysis results (Two step regression)}

In the last part we have showing that Islamic bank in GCC countries are efficient in most cases. We show that the subprime loans crisis didn't affect their efficiency. Now, we try to explain the main factors that explain this efficiency, according the regression analysis via panel data approach.

Appendix C (Table 8 and Table 9) presents the results of Spearman Rho test respectively for two models (CRS and VRS). This test looks for individual statistical associations of our explanatory variables with the variable to explain. The main objective of this results consists to detect variables which able to generate multicollinearity problem. The results show, for the first model, that the variables population density and management quality are statistically significant at $1 \%$ and positively correlated to efficiency under the CRS hypothesis, (Table 8). However, concerning our second model, the results show that the variable size is positively correlated to efficiency with a level of 5\%, (Table 9). Concerning the variables ROA and GDP, they are significant at $10 \%$ and they positively affect efficiency.

Appendix C, Table 10 and Table 11, display respectively the results of normality test ${ }^{11}$ (Shapiro-Wilk test), respectively for CRS and VRS models. This test rejects the normality condition for both model (CRS and VRS). This preliminary analysis of Shapiro-Wilk test and Spearman Rho test allow us to retain the relevance variables to must be included in models in order to avoid unbiased estimations. So, our model according CRS and VRS assumption are written respectively as follow:

$$
\begin{aligned}
& \operatorname{SECRS}_{i, t}=\alpha_{0}+\beta_{0} \operatorname{GDP}_{i, t}+\beta_{1} P D_{i, t}+\beta_{2} A Q_{i, t}+\beta_{3} A Q_{i, t}+\beta_{4} R O A_{i, t}+\varepsilon_{i, t} \\
& \operatorname{SEVRS}_{i, t}=\alpha_{0}+\beta_{0} G D P_{i, t}+\beta_{1} P D_{i, t}+\beta_{2} R C P_{i, t}+\beta_{3} A Q_{i, t}+\beta_{4} R O E_{i, t}+\varepsilon_{i, t}
\end{aligned}
$$

To estimate models 1 (eq.10) and 2 (eq.11) according panel data approach, we must at the beginning to verify if there are homogeneous or heterogeneous specifications of the data generating process. Table 12 (appendix D) displays the results of the homogeneity test which show the presence of individual effects for our models (eq.10 and eq.11). Then, Table 13 (appendix D) the Haussmann test which serves to discriminate the fixed and random effects. The table shows that the choice of the fixed effects for our two models was the most appropriate. Finally, we use the bootstrapping technique to avoid dependency problems and to overcome the shortcomings and biases that may result from the use of non parametric methods. Indeed, most studies that use the two-level DEA do not employ appropriate bootstrapping techniques, and their results may be biased (Fethi and Pasiouras, 2010). So, to overcome

\footnotetext{
${ }^{11}$ This test allows us to take the relevance test to make out the dependence.
} 
this statistical problem, we decided to use the bootstrapping technique to eliminate possible bias in our results. The following table presents the results panel data estimation.

Table 3: results of panel regression analysis

\begin{tabular}{|c|c|c|}
\hline Variable & $\mathbf{1}^{\text {st }}$ model results (eq.10) & $2^{2^{\text {nd }}}$ model results (eq.11) \\
\hline GDP & Positive*** & Positive*** \\
\hline Population density & Positive*** & Positive*** \\
\hline Equity ratio & & $\begin{array}{l}\text { Positive (Non significant) } \\
\end{array}$ \\
\hline Assets Quality & Negative (Non significant) & Negative (Non significant) \\
\hline Management Quality & Negative** & Negative** \\
\hline ROA & Positive (Non significant) & \\
\hline ROE & & Negative (Non significant) \\
\hline $\mathbf{R}^{2}$ adjusted & 0,2069 & 0,1188 \\
\hline
\end{tabular}

Table 3 shows that the macroeconomic variable GDP is positively and significantly correlated with Islamic banks efficiency and this according to our two models (eq.10 and eq.11). That is to say that when the GDP of a country increases, Islamic banks operating in this country become more efficient. This is consistent with that found by Kablan (2007).

As regards to the variable "Population density", measured by the population density of the concerned country, is positively and significantly correlated with Islamic banks efficiency at $1 \%$ level for both models (eq. 10 and eq.11). So, if population density increases, Islamic banks efficiency increases too. This result is very logical; indeed with the increase of the population density, the number of potential customers of Islamic banks increases, which raise consequently the efficiency of those banks. However, this variable has not been much used in the literature; the only one who has incorporated in his study is Kablan (2007). Our results differ from the work of Kablan (2007). He showed that the population density is negatively correlated with Islamic banks efficiency.

Furthermore, these results highlight that "Management Quality" is significantly (5\%) and negatively correlated with Islamic banks efficiency, and whatever hypothesis used (CRS or VRS). This relationship is consistent with our expectations. Indeed, more the bank has a strong management team, which monitors its interest and tries its best to keep it moving, more the bank will be efficient. The result joins perfectly, in every respect, the most studies that have addressed this variable. Indeed, Sufian (2009) and Sufian and Muhd-Zulkhibri (2007) both found results similar to ours.

The bank assets quality is a variable which has relevance information's on the credit of the bank. However, Table 3 shows that this variable is not significant. Our results are similar to those identified by Sufian and MuhdZulkhibri (2007). Despite the none-significantly of assets quality, its sign is negative. This negative correlation was found previously in the studies of Sufian (2009), Kwan and Eisenbeis (1995), Resti (1997), and Barr and al. (2002).

Our $1^{\text {st }}$ model's (eq.10) results have also shown that the variable ROA is positively correlated with Islamic banks efficiency but this relationship is not statistically significant. This result agrees with that of Yudistira (2004) who found that the Islamic banks profitability does not influence their efficiencies. However, the two variables used in the $2^{\text {nd }}$ model (eq.11) to measure the profitability of banks, ie, ROE and Equity ratio are respectively negatively and positively correlated with Islamic banks efficiency without being significant. This result joins, in particular, that of Yudistira (2004) who found that the Islamic banks profitability does not influence their efficiencies. Thus, a profitable bank is not necessarily efficient.

Finally, we found that the only real difference between the two models (eq.10 and eq.11) is the adjusted $\mathrm{R}^{2}$ which is $20,69 \%$ for the CRS hypothesis against $11,88 \%$ for the model based on the VRS hypothesis. This result may indicate that the CRS assumption is more appropriate in measuring efficiency scores of Islamic banks in the GCC region rather than the VRS assumption. However, according to the literature, we always find that the CRS hypothesis is only justified when banks are operating at an optimal scale. But, in practice, banks and companies in general may face, either economies of scale, or diseconomies of scale. Thus, if we set the false hypothesis of CRS while banks are not operating at optimal scale, the measures identified of technical inefficiency will be contaminated 
by inefficiency of scale. So, according to Banker and al. (1984), Sufian (2007-2009), if there is a difference between efficiency under CRS hypothesis and under VRS hypothesis, it is mainly due to inefficiency of scale has not been severed from the rest of the components of efficiency.

\section{V- CONCLUSION}

The present study investigates the efficiency of the Islamic bank in GCC countries around the subprime crisis of 2008. The efficiency estimates of individual banks are evaluated by using the DEA approach. Two different approaches are evaluated; the CRS and VRS in order to measure respectively the overall technical efficiency and the pure technical efficiency. A regression panel analysis is employed to examine the relationship between efficiency scores derived from the DEA to a set of explanatory variables combined between macroeconomic variables (Gross Domestic Product, Population density, Concentration) and microeconomic variables (Market share, Bank size, Return on Equity, Return on Assets, Liquidity, Management Quality, Assets Quality). We find that on average the Islamic bank's efficiency increases as the GDP of the country where it operates increases. If we look a little closer, we will notice that the countries hosting the more Islamic banks are those having high levels of GDP. Also, our results show that population density is affecting positively the Islamic banks' efficiency. Furthermore, an Islamic bank having a management of a good quality, according to our results, may present efficiency levels higher than a bank with bad quality management.

We think it would be interesting to dig even more these two factors, namely, population density and management quality. Since, we can, for a further study, focus on the religion of the Islamic banks' customers. Are they more likely to be Muslims or the factor of the religion is not material for the efficiency of Islamic banks? It would, also, be very useful to try to measure the management quality using qualitative data.

\section{AUTHOR INFORMATION}

Zied Ftiti, Researcher at IPAG Business School, Paris-France, Professor at University of Tunis, High Business Institute. Member of Department of Quantitative methods and Economics in ISG of Tunis, FIESTA UMR, Tunisia. E-mail: Zied.Ftiti@isg.rnu.tn (Corresponding author).

Olfa Nafti, University of Manouba, Tunisia. ISCAE-Accounting department - Member of LIG laboratory, Tunisia. E-mail: olfa.nafti@iscae.rnu.tn

Safa Sreiri, University of Carthage, IHEC - Accounting department, Tunisia. E-mail: safa-sr@ hotmail.com

\section{BIBLIOGRAPHY}

1. Abhiman, D., \& Saibal, G. (2009). Financial Deregulation and Profit Efficiency: A Non-Parametric Analysis of Indian Banks. Munich Personal RePEc Archive.

2. Barr, R. S., Killgo, K. A., Siems, T. F., \& Zimmel, S. A. (2002). Evaluating the productive efficiency and performance of U.S. commercial banks. Managerial Finance, 28 (8), 3-25.

3. Banker, R. D., Charnes, A., \& Cooper, W. W. (1984). Some models for estimating technical and scale inefficiencies in data envelopment analysis. Management Science 30 (9), 1078-1092.

4. Berger, A. N., Hunter, W. C., \& Timme, S. G. (1993). The efficiency of financial institutions: A review and preview of research past, present, and future. Journal of Banking and Finance, 17, 221-249.

5. Benston, G.J. (1965) Branch Banking and Economies of Scale. Journal of Finance, 20 (2), 312-331.

6. Chapra, M. Umer. (2008). The Global Financial Crisis: Can Islamic Finance Help Minimize The Severity and Frequency of Such A Crisis In The Future?. A paper prepared for presentation at Islamic Development Bank.

7. Caprio, G. Jr., \& Summers, L. (1993). Finance and Its Reform: Beyond Laissez-Faire. Washington, D.C.: Working Paper Series, 1171.

8. Casu B., Molyneux P. (2000). A Comparative Study of Efficiency in European Banking, Wharton School Research Paper, $\mathrm{N}^{\circ} 00 / 17$.

9. Casu, B., Molyneux, P. (2003). A comparative study of efficiency in European banking. Applied 
Economics, 35, 1865-1876.

10. Charnes, A., Cooper, W. W., \& Rhodes, E. (1978). Measuring the efficiency of decision making units. European Journal of Operations Research, 2, 429-444.

11. Coelli, T. J., Rao, D. S. P., O'Donnell, C. J. \& Battese, G. E. (2005). An Introduction to Efficiency and Productivity Analysis. Second ed. New York: Springer.

12. Danesh, I. A. (2007). An Investigation of Islamic Banks Performance: A Comparison with Conventional Banks. Thèse soutenue en vue de l'obtention d'un Master en sciences de Management et de Finance, Cranfield University School Of Management.

13. Dar, H., \& Presley, J. R. (2000). Lack of profit loss sharing in Islamic banking: management and control imbalances. International Journal of Islamic Financial Services, 2(2).

14. Dar, H. (2003). Handbook of International Banking. Edward Elgar, Chapter8.

15. DeYoung, R. (1997). X-Efficiency and Management Quality in National Banks. Journal of Financial Services Research, Vol. 15, No. 2.

16. Drake, L., \& Hall, M. (2003). Efficiency in Japanese Banking: An Empirical Analysis. Journal of Banking and Finance, 27, 891-917.

17. Drake, L., Hall, M.J.B., Simper, R. (2006). The impact of macroeconomic and regulatory factors on bank efficiency: a non-parametric analysis of Hong Kong's banking system. J. Bank. Finan. 30 (5), 1443-1466.

18. Elhiraika, A. B. (1998). Macroeconomic Instability, Financial Repression and Islamic Banking in Sudan. Journal of Economics and Management, 6 (2) Special Issue, 61-86.

19. El-Gamal, M.A., \& Inanoglu, H. (2005). Inefficiency and heterogeneity in Turkish banking: 1990-2000. Journal of Applied Econometrics, 20 (05), 661-664.

20. Elyasiani, E. \& Mehdian, S. (1990). Efficiency in commercial banking industry, a production frontier approach. Applied Economics, 22, pp.539-51.

21. Fethi, M. D., \& Pasiouras, F. (2010). Assessing bank efficiency and performance with operational research and artificial intelligence techniques: A survey. European Journal of Operational Research, 204, 189-198.

22. Ghayad, R. (2008). Corporate governance and the global performance of Islamic banks, Humanomics, 24 (3), pp. 207-216.

23. Gonzales-Hermosillo, B., Pazarbasioglu, C. \& Billings, R. (1997). Determinants of Banking System Fragility: A Case Study of Mexico. IMF Staff Papers, 44 (3), 295-315.

24. Grosskopf, S. (1996). Statistical Inference and Nonparametric Efficiency: A Selective Survey, Journal of Productivity Analysis, 7, pp. 161-176.

25. Hamim, S.A.M., Naziruddin, A., \& Elhabshi, S. M. (2008). Efficiency and competition of Islamic banking in Malaysia. Humanomics, Vol. 24(1), 28-48

26. Haron, S. (2004). Determinants of Islamic Bank Profitability. The Global Journal of Finance and Economics, vol (1).

27. Hassan, M. K. \& Bashir, A. H. M. (2003). Determinants of Islamic Banking Profitability. 10th ERF Annual Conference, 16th - 18th December, Morocco.

28. Hasan, Z. (2005). Islamic banking at the crossroads: theory versus practice. Islamic Perspectives on Wealth Creation, 11-25.

29. Hellmann, T., Murdock, K., \& Stiglitz, J. (2000). Liberalization, Moral Hazard in Banking, and Prudential Regulation: Are Capital Requirements Enough?. American Economic Review, Vol. 90 (1), 147-65.

30. Hassan, Z. (2004). Measuring efficiency of Islamic banks: criteria, methods, and social priorities. MPRA working papers.

31. Hassan, M.K. (2005). The cost, profit and X-efficiency of Islamic Banks. Paper presented at the 12th ERFAnnual Conference, 19, 21 December.

32. Hassoune, A. (2010). Enjeux et défis pour la finance islamique. Colloque Finance islamique : réalités et perspectives, le 15 avril 2010, Tunis

33. Honohan, P. 1997. Banking System Failures in Developing and Transition Countries: Diagnosis and Prediction. Bank for International Settlements Working Paper.

34. Iqbal, M., \& Al-Omar, F. A. (2000). Some Strategic Suggestions for Islamic Banking in the $21^{\text {st }}$ Century. Review of Islamic Economics, 9, 37-56.

35. Kamaruddin., Mohammad S. S., Badrul H., \& Rohani, M. (2008). Assessing Production Efficiency of Islamic Banks and Conventional Bank Islamic Windows in Malaysia. International Journal of Business and Management Research, 1(1): 31-48. 
36. Kiyota, H. (2009). Efficiency of Commercial Banks in Sub-Saharan Africa: A Comparative Analysis of Domestic and Foreign Banks. A paper prepared for the CSAE conference 2009 on "Economic Development in Africa" held at the University of Oxford.

37. Lindgren, C-J., Garcia, G., \& Saal, M. (1996). Bank Soundness and Macroeconomic Policy. International Monetary Fund, 215 pages.

38. Loayza, N., \& Shankar, R. (2000). Private Saving in India. World. Ban. Econ. Rev, 14, 571-594.

39. Miotti L., L. Abdelli \& F. Malige (1998), «Fragilité des systèmes bancaires des économies émergentes », Caisse des Dépôts et Consignations, Zones émergentes, $\mathrm{n}^{\circ} 4$.

40. Plihon, D. (1996). La montée en puissance de la finance spéculative, dans Turbulences et spéculations. Sous la direction d'A. Cartapanis, Economica

41. Sarker, M.A.A. (1999), "Islamic banking in Bangladesh: performance, problems, and prospects. International Journal of Islamic Financial Services, 1(3).

42. Sealey, C., \& Lindley, J.T. (1977). Inputs, outputs and a theory of production and cost at depository financial institutions. Journal of Finance 32 (4), 1251-1266.

43. Sufian, F. (2007). Trends in the efficiency of Singapore's commercial banking groups: a non-stochastic frontier DEA window analysis approach. Int. J. Product. Perform. Manage, 56, 99-136.

44. Sufian, F. (2009). Determinants of bank efficiency during unstable macroeconomic environment: Empirical evidence from Malaysia. Research in International Business and Finance, 23, 54-77.

45. Sufian, F., \& Muhd-Zulkhibri, A. M. (2007). Bank Ownership, Characteristics and Performance: A Comparative Analysis of Domestic and Foreign Islamic Banks in Malaysia. MPRA Paper, $N^{\circ} 12131$

46. Wheelock, D. C., \& Wilson, P. (2000). Why do Banks Disappear? The Determinants of U.S. Bank Failures and Acquisitions. The Review of Economics and Statistics. 82 (1), 127-138.

47. Yudistira, D. (2004). Efficiency in Islamic banking: An empirical analysis of 18 Banks. Islamic Economic Studies, 12 (1).

48. Miller,S.,and Noulas,A.(1996).The technical efficiency of large bank production. Journal of Banking and Finance, 20, 495-509.

49. Kwan, S. H., \& Eisenbeis, R. (1995). An analysis of inefficiencies in banking. Journal of Banking and Finance, 19 (3-4), pp.733-734.

50. Kablan, S. (2007). Measuring bank efficiency in developing countries: The case of WAEMU (West African Economic Monetary Union), African Economic Conference.

51. Lozano-Vivasa, A., \& Pasiouras, F. (2010). The impact of non-traditional activities on the estimation of bank efficiency: International evidence. Journal of Banking and Finance, 1-14.

52. Resti. A. (1997). Evaluating the cost-efficiency of the Italian Banking System: What can be learned from the joint application of parametric and non-parametric techniques. Journal of Banking \& Finance 21, 221 250.

53. Wilson. R. (2009). The development of Islamic Finance in the GCC.[Power points slides]. Retrieved from: http://www1.cimaglobal.com/Documents/Islamic\%20finance/2011/Press\%20cuttings/development-of-IFin-the-GCC.pdf

54. Xue M. and P.T. Harker, (1999). Overcoming the Inherent Dependency of DEA Efficiency Scores: A Bootstrap Approach, Working paper 99 -17 (Financial Institution Center, The Wharton School, University of Pennsylvania). 


\section{APPENDICES}

Appendix A: Descriptive Statistics of Banks inputs and outputs.

Table 4: Descriptive statistics of banks inputs

\begin{tabular}{|c|c|c|c|c|c|}
\hline & Inputs & Mean & Minimum & Maximum & $\begin{array}{l}\text { Standard } \\
\text { Variation }\end{array}$ \\
\hline & Deposits & 1553,986 & 0 & 20221,445 & 4087,722 \\
\hline \multirow[t]{3}{*}{2005} & Equity & 2094,846 & 0 & 22378,392 & 4423,012 \\
\hline & Labor & 26,469 & 0 & 210,916 & 41,276 \\
\hline & Deposits & 2011,788 & 0 & 21059,870 & 4659,590 \\
\hline \multirow[t]{3}{*}{2006} & Equity & 2935,715 & 0 & 25191,461 & 5392,481 \\
\hline & Labor & 42,736 & 0 & 262,684 & 57,280 \\
\hline & Deposits & 3968,912 & 1,396 & 27659,016 & 8616,968 \\
\hline \multirow[t]{3}{*}{2007} & Equity & 6165,284 & 404,835 & 33240,320 & 7554,049 \\
\hline & Labor & 130,569 & 16,508 & 530,471 & 8981,860 \\
\hline & Deposits & 6859,981 & 150,226 & 37469,122 & 7250,257 \\
\hline \multirow[t]{3}{*}{2008} & Equity & 10000,229 & 4999,288 & 45122,198 & 8115,597 \\
\hline & Labor & 215,097 & 3345,046 & 589,066 & 91,374 \\
\hline & Deposits & 9144,917 & 75,136 & 39945,035 & 7555,815 \\
\hline \multirow[t]{2}{*}{2009} & Equity & 12879,744 & 7946,206 & 50070,506 & 8785,018 \\
\hline & Labor & 135,754 & 5569,704 & 533,262 & 97,374 \\
\hline \multicolumn{6}{|c|}{ Table 5: Descriptive statistics of banks outputs } \\
\hline \multirow{5}{*}{2005} & Outputs & Moyenne & Minimum & Maximum & Ecart Type \\
\hline & Financing & 2018,349 & 0 & 21480,206 & 4272,474 \\
\hline & Other revenues & 93,675 & 0 & 1844,633 & 338,757 \\
\hline & Liquid assets & 209,207 & 0 & 2963,485 & 563,434 \\
\hline & Financing & 2828,183 & 0 & 24063,918 & 5295,015 \\
\hline \multirow[t]{3}{*}{2006} & Other revenues & 134,304 & 0 & 1816,778 & 356,145 \\
\hline & Liquid assets & 250,877 & 0 & 2850,878 & 559,780 \\
\hline & Financing & 5801,298 & 393,735 & 31641,483 & 8616,968 \\
\hline \multirow[t]{3}{*}{2007} & Other revenues & 208,994 & 449,182 & 2381,423 & 513,724 \\
\hline & Liquid assets & 370,394 & 530,446 & 3759,993 & 791,681 \\
\hline & Financing & 9457,409 & 4721,079 & 43252,632 & 7837,026 \\
\hline \multirow[t]{3}{*}{2008} & Other revenues & 284,299 & 83,244 & 2437,096 & 517,037 \\
\hline & Liquid assets & 538,475 & 138,067 & 3916,171 & 801,715 \\
\hline & Financing & 12563,930 & 7841,217 & 46293,949 & 8236,262 \\
\hline \multirow[t]{2}{*}{2009} & Other revenues & 470,845 & 264,824 & 3423,097 & 613,866 \\
\hline & Liquid assets & 856,830 & 418,291 & 3947,057 & 943,372 \\
\hline
\end{tabular}


Appendix B: Efficiency Score Results

Table 6: Descriptive statistics of efficiency score

\begin{tabular}{|c|c|c|c|c|c|}
\hline Variables & Years & Min & $\operatorname{Max}$ & Mean & SE \\
\hline \multirow{5}{*}{ Efficiency score under CRS } & 2005 & 0,384 & 1,000 & 0,816 & 0,156 \\
\hline & 2006 & 0,488 & 1,000 & 0,824 & 0,153 \\
\hline & 2007 & 0,497 & 1,000 & 0,788 & 0,154 \\
\hline & 2008 & 0,547 & 1,000 & 0,788 & 0,143 \\
\hline & 2009 & 0,416 & 1,000 & 0,792 & 0,185 \\
\hline \multirow{5}{*}{ Efficiency score under VRS } & 2005 & 0,387 & 1,000 & 0,847 & 0,161 \\
\hline & 2006 & 0,491 & 1,000 & 0,864 & 0,155 \\
\hline & 2007 & 0,497 & 1,000 & 0,831 & 0,158 \\
\hline & 2008 & 0,547 & 1,000 & 0,854 & 0,158 \\
\hline & 2009 & 0,417 & 1,000 & 0,851 & 0,192 \\
\hline
\end{tabular}

Table 7: Descriptive statistics of explicative variables

\begin{tabular}{|c|c|c|c|c|}
\hline Variables & Min & Max & Mean & SE \\
\hline GDP & 7253,926 & 145343,100 & 37873,960 & 34889,180 \\
\hline PD & 0,000 & 2873,149 & 1167,341 & 1268,852 \\
\hline INDHH & 112,532 & 2243115,000 & 628478,800 & 612128,600 \\
\hline $\mathrm{RCP}$ & 0,000 & 6,688 & 0,896 & 1,251 \\
\hline $\mathrm{AQ}$ & 0,000 & 1,404 & 0,047 & 0,152 \\
\hline MQ & 0,000 & 0,620 & 0,035 & 0,088 \\
\hline LQ & 0,000 & 9,440 & 1,670 & 1,870 \\
\hline $\mathrm{ROA}$ & $-2,160$ & 3,277 & 0,082 & 0,462 \\
\hline $\mathrm{ROE}$ & $-7,397$ & 4,923 & 0,102 & 1,165 \\
\hline BS & 0,000 & 183,117 & 39,439 & 41,270 \\
\hline MS & 0,000 & 176,831 & 32,725 & 39,641 \\
\hline
\end{tabular}

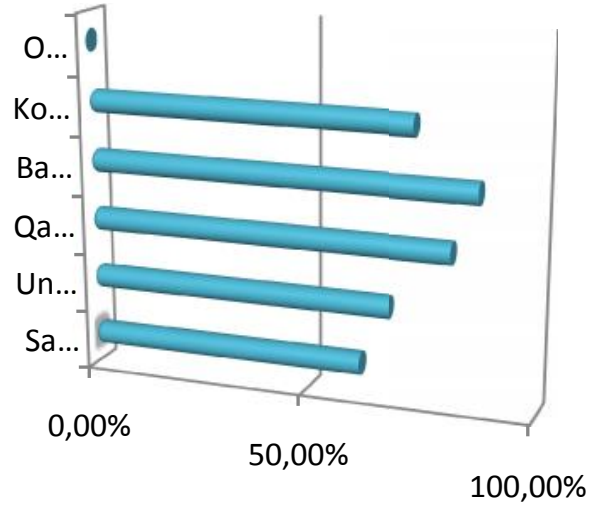

$\square$ Mean of efficiency scores CRS

Figure 3: Mean of efficiency score under CRS model

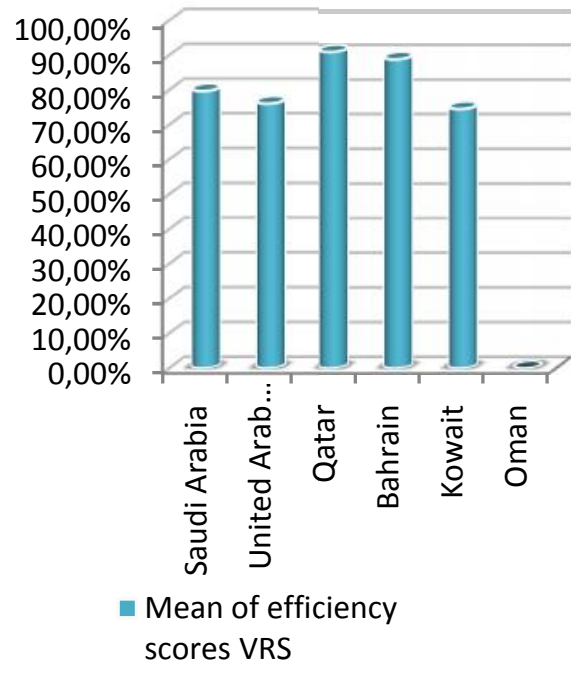

Figure 4: Mean of efficiency score under VRS model 
Appendix C: Correlation Analysis and Normality Test.

Table 8: Correlation between efficiency score, under CRS (eq.10), and dependant variables

\begin{tabular}{|c|c|c|}
\hline Variables & Spearman Rho & p-value \\
\hline GDP & 0,4048 & $0,0000 * * *$ \\
\hline PD & 0,3154 & $0,0001 * * *$ \\
\hline INDHH & 0,3772 & $0,0000 * * *$ \\
\hline $\mathrm{RCP}$ & 0,4157 & $0,0000 * * *$ \\
\hline AQ & $-0,0976$ & 0,2513 \\
\hline QM & 0,2891 & $0,0005^{* * * *}$ \\
\hline LQ & 0,4527 & $0,0000 * * *$ \\
\hline ROA & 0,2809 & $0,0008 * * *$ \\
\hline ROE & 0,1785 & $0,0349 * *$ \\
\hline BS & 0,2981 & $0,0003 * * *$ \\
\hline MS & $-0,0258$ & 0,7625 \\
\hline
\end{tabular}

Table 9: Correlation between efficiency score, under CRS, (eq-11), and dependant variables

\begin{tabular}{|c|c|c|}
\hline Variables & Spearman Rho & p-value \\
\hline GDP & 0,1458 & $0,0856^{*}$ \\
\hline PD & 0,1238 & 0,1450 \\
\hline INDHH & 0,1007 & 0,2367 \\
\hline $\mathrm{RCP}$ & 0,1177 & 0,1661 \\
\hline AQ & $-0,1107$ & 0,1930 \\
\hline QM & 0,0235 & 0,7828 \\
\hline LQ & 0,1654 & $0,0509 *$ \\
\hline ROA & 0,1107 & 0,1928 \\
\hline ROE & 0,0625 & 0,4629 \\
\hline BS & 0,1692 & $0,0457 * *$ \\
\hline MS & $-0,1065$ & 0,2104 \\
\hline
\end{tabular}

Table 10: Normality test (Model 1-CRS-eq.10)

\begin{tabular}{lcccc}
\hline \hline \multicolumn{1}{c}{ Variable } & $\mathbf{W}$ & $\mathbf{V}$ & $\mathbf{Z}$ & Prob>z \\
SECRS & 0,958 & 4,611 & 3,452 & $0,000^{* * *}$ \\
GDP & 0,752 & 27,406 & 7,481 & $0,000^{* * *}$ \\
PD & 0,779 & 24,372 & 7,216 & $0,000^{* * *}$ \\
INDHH & 0,803 & 21,708 & 6,955 & $0,000^{* * *}$ \\
RCP & 0,700 & 33,134 & 7,910 & $0,000^{* * *}$ \\
AQ & 0,311 & 76,087 & 9,789 & $0,000^{* * *}$ \\
QM & 0,384 & 68,025 & 9,536 & $0,000^{* * *}$ \\
LQ & 0,702 & 32,858 & 7,891 & $0,000^{* * *}$ \\
ROA & 0,523 & 52,620 & 8,955 & $0,000^{* * *}$ \\
ROE & 0,458 & 59,760 & 9,243 & $0,000^{* * *}$ \\
BS & 0,701 & 32,992 & 7,901 & $0,000^{* * *}$ \\
MS & 0,706 & 32,484 & 7,865 & $0,000^{* * *}$ \\
\hline \hline
\end{tabular}

Table 11: Normality test (Model 2-VRS-eq.11)

\begin{tabular}{lcccc}
\hline \multicolumn{1}{c}{ Variable } & $\mathbf{W}$ & $\mathbf{V}$ & $\mathbf{Z}$ & Prob>z \\
SEVRS & 0,900 & 10,995 & 5,416 & $0,000^{* * *}$ \\
GDP & 0,751 & 27,345 & 7,474 & $0,000^{* * *}$ \\
PD & 0,779 & 24,197 & 7,197 & $0,000^{* * *}$ \\
INDHH & 0,800 & 21,895 & 6,971 & $0,000^{* * *}$ \\
RCP & 0,701 & 32,802 & 7,884 & $0,000^{* * *}$ \\
AQ & 0,311 & 75,583 & 9,770 & $0,000^{* * *}$ \\
QM & 0,385 & 67,510 & 9,515 & $0,000^{* * *}$ \\
LQ & 0,701 & 32,752 & 7,881 & $0,000^{* * *}$ \\
ROA & 0,525 & 52,117 & 8,930 & $0,000^{* * *}$ \\
ROE & 0,460 & 59,267 & 9,221 & $0,000^{* * *}$ \\
BS & 0,698 & 33,081 & 7,904 & $0,000^{* * *}$ \\
MS & 0,705 & 32,334 & 7,852 & $0,000^{* * *}$ \\
\hline \hline
\end{tabular}

(C) 2013 The Clute Institute http://www.cluteinstitute.com/ 
Appendix D: Regression Analysis Results

Table 12: Results of Fixed effect test

\begin{tabular}{lcc}
\hline \hline & $\boldsymbol{F}$ (Fischer) & Prob $>\boldsymbol{F}$ \\
CRS Model (eq.10) & $\mathrm{F}(29,105)=8,88$ & 0,0000 \\
VRS Model (eq.11) & $\mathrm{F}(29,104)=10,91$ & 0,0000 \\
\hline \hline
\end{tabular}

Table 13: Results of Hausman Test

\begin{tabular}{|c|c|c|c|}
\hline & \multicolumn{2}{|c|}{ Khi Deux } & Prob > Khi Deux \\
\hline CRS Model (eq.10) & \multicolumn{2}{|c|}{ Khi $2(3)=11,80$} & 0,0081 \\
\hline VRS Model (eq.11) & \multicolumn{2}{|c|}{ Khi $2(4)=13,50$} & 0,0091 \\
\hline Variables & " Coefficient & 7 & P-value \\
\hline GDP & 0,0000005 & 2,63 & $0,009 * * *$ \\
\hline PD & 0,0000103 & 3,95 & $0,000 * * *$ \\
\hline AQ & $-0,2150839$ & $-0,19$ & 0,850 \\
\hline QM & $-0,2977601$ & $-1,98$ & $0,048 * *$ \\
\hline ROA & 0,0497492 & 0,05 & 0,962 \\
\hline Constant & 0,0182053 & 40,20 & 0,000 \\
\hline Adjusted R ${ }^{2}$ & 0,2069 & & \\
\hline \multicolumn{4}{|c|}{ Table 15-Bootstrapping results (VRS Model-eq.11-) } \\
\hline Variables & Coefficient & $\mathbf{Z}$ & P-value \\
\hline GDP & 0,0000004 & 2,24 & $0,025^{* *}$ \\
\hline PD & 0,0000115 & 1,90 & $0,057 * * *$ \\
\hline $\mathrm{RCP}$ & 0,0185880 & 0,67 & 0,506 \\
\hline AQ & $-0,2194281$ & $-0,63$ & 0,527 \\
\hline QM & $-0,4184511$ & $-1,98$ & $0,047 * *$ \\
\hline ROE & $-0,0250998$ & $-0,58$ & 0,562 \\
\hline Constant & 0,0204074 & 39,83 & 0,000 \\
\hline Adjusted R ${ }^{2}$ & $\mathbf{0 , 1 1 8 8}$ & & \\
\hline
\end{tabular}

